$$
\text { Conf } 9507122--4
$$

UCRL-JC-120779

PREPRINT

\title{
Performance Results for BEAMLET: A Large Aperture, Multipass Nd: Glass Laser
}

J. H. Campbell, C. E. Barker, B. M. VanWonterghem,

D. R. Speck, W. C. Behrendt, J. R. Murray,

J. A. Caird, D. E. Decker, and I. C. Smith

This paper was prepared for submittal to the

CLEO/Pacific Rim ‘95

Chiba, Japan

July 11-14, 1995

April 11, 1995

This is a preprint of a paper intended forpublication in a journal or proceedings. Since changes may be made before publication, this preprint is made available with the understanding that it will not be cited or reproduced without the permission of the author.<smiles>[LiH]</smiles>

DISTRIBUTION OF THIS DOCUMENT IS UNLIMITED 


\section{DISCLAIMER}

This document was prepared as an account of work sponsored by an agency of the United States Government. Neither the United States Government nor the University of California nor any of their employees, makes any warranty, express or implied, or assumes any legal liability or responsibility for the accuracy, completeness, or usefulness of any information, apparatus, product, or process disclosed, or represents that its use would not infringe privately owned rights. Reference herein to any specific commercial product, process, or service by trade name, trademark, manufacturer, or otherwise, does not necessarily constitute or imply its endorsement, recommendation, or favoring by the United States Government or the University of California. The views and opinions of authors expressed herein do not necessarily state or reflect those of the United States Government or the University of California, and shall not be used for advertising or product endorsement purposes. 


\section{DISCLAIMER}

Portions of this document may be illegible in electronic image products. Images are produced from the best available original document. 


\title{
Performance Results for Beamlet: A Large Aperture, Multipass Nd: Glass Laser
}

\author{
John H. Campbell, Charles E. Barker, Bruno M. VanWonterghem, \\ David R. Speck, William C. Behrendt, John R. Murray, \\ John A. Caird, Derek E. Decker and Ian C. Smith \\ University of California \\ Lawrence Livermore National Laboratory \\ P. O. Box 808, L-490, Livermore, CA $94551-9900$ \\ Phone (510) 422-6497/Fax (510) 422-7748 \\ CLEO/Pacific Rim '95 \\ Makuhari Messe Convention Center \\ Chiba, Japan \\ July 11-14, 1995
}

\begin{abstract}
The Beamlet laser is a large aperture, flashlamp pumped Nd: glass laser that is a scientific prototype of an advanced Inertial Fusion laser. Beamlet has achieved third harmonic, conversion efficiency of near $80 \%$ with its nominal $35 \mathrm{~cm} \times 35 \mathrm{~cm}$ square beam at mean $3 \omega$ fluences in excess of $8 \mathrm{~J} / \mathrm{cm}^{2}$ (3-ns). Beamlet uses an adaptive optics system to correct for aberrations and achieve less than $2 x$ diffraction limited far field spot size.
\end{abstract}

${ }^{*}$ Work performed under the auspices of the U.S. Department of Energy by Lawrence Livermore National Laboratory under Contract No. W-7405-Eng- 48

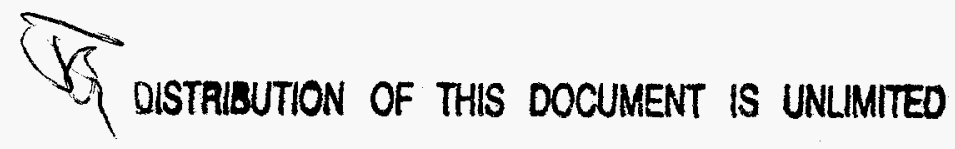


Performance Results for Beamlet: A Large Aperture, Multipass Nd: Glass Laser

\author{
John H. Campbell, Charles E. Barker, Bruno M. VanWonterghem, \\ David R. Speck, William C. Behrendt, John R. Murray, \\ John A. Caird, Derek Decker and Ian C. Smith \\ University of California \\ Lawrence Livermore National Laboratory \\ P. O. Box 808, L-490, Livermore, CA $94551-9900$ \\ Phone (510) 422-6497/Fax (510) 422-7748
}

The US Department of Energy has proposed to build a National Ignition Facility (NIF) for Inertial Confinement Fusion (ICF) research [1]. The laser driver of this facility will consist of a frequency-tripled, Nd: glass laser system capable of irradiating fusion targets at an energy and power of 1.8 MJ and 500 TW. The NIF laser will consist of 192 independent "beamlets" arranged in four large, compact arrays 4 beamlets high and 12 wide.

We have recently completed construction and preliminary testing of one prototype Beamlet (Fig 1)[2]. This prototype Beamlet laser has a $35 \mathrm{~cm} \times 35 \mathrm{~cm}$ square aperture and uses a multipass architecture; this is the first attempt to employ such a design at this scale. The $36 \mathrm{~m}$ long main laser cavity uses a unique full aperture $(35 \mathrm{~cm})$ plasma-electrode pockels cell [3] and polarizer in an angularity multiplexed design to switch the $\sim 3$ ns pulse out of the cavity. The pulse is contained in the cavity for a total of four passes through a group of 11 full aperture flashlamp pumped $\mathrm{Nd}$ :phosphate glass amplifiers[4]. The output pulse from the cavity then makes a single pass through a 
"booster" amplifier section (composed of five more amplifier modules) that is driven heavily into saturation. The $1 \omega$ output from the booster amplifiers passes through a final spatial filter and then enters a dual crystal frequency converter. The frequency converter uses a type I/type II third harmonic generation scheme consisting of a 1.05$\mathrm{cm}$ thick KDP doubler and 0.95-cm thick KD*P (80\% deuterated) tripler. In our experiments we have used both $32 \times 32 \mathrm{~cm}^{2}$ and $37 \times 37 \mathrm{~cm}^{2}$ crystals that can support approximately $30 \times 30$ and $34 \times 34 \mathrm{~cm}^{2}$ input beams, respectively (the smaller crystals were tested first because of the shorter time needed to grow them); the boules from which the larger crystals were cut took about 2 years to grow and weigh about 0.5 ton[5].

Table 1 and 2 summarizes the main performance characteristics of the laser at 1054 and $351 \mathrm{~nm}$, respectively. Initial frequency conversion tests were carried out at approximately $30 \times 30 \mathrm{~cm}^{2}$ beam size; tests at the larger aperture $\left(34 \times 34 \mathrm{~cm}^{2}\right)$ are in progress and will be reported at the conference.

\section{References}

1. National Ignition Facility Conceptual Design Report, Lawrence Livermore National Laboratory, Livermore, CA, UCRL-PROP-117093, May 1994.

2. B. M. VanWonterghem et al., "System Description and Initial Performance Results for Beamlet", ICF Quarterly Report, Vol. 5 (1) 1994; LLNL report UCRL-LR-105821-94-1. 3. M. A. Rhodes et al., "Design and Performance of the Beamlet Optical Switch", ICF Quarterly Report, Vol. 5 (1) 1994; LLNL report UCRL-LR-105821-94-1.

4. A. C. Erlandson et al., "Design and Performance of the Beamlet Amplifiers", ICF Quarterly Report, Vol. 5 (1) 1994; LLNL report UCRL-LR-105821-94-1.

5. J. H. Campbell et al., "Large Aperture, High Damage Threshold Optics for Beamlet" ,ICF Quarterly Report, Vol. 5 (1) 1994; LLNL report UCRL-LR-105821-94-1. 
Table 1. Summary of measured Beamlet output energy vs. pulse length at 1054 . $34 \times 34 \mathrm{~cm}^{2}$ beam (effective area $971 \mathrm{~cm}^{2}, 84 \%$ aperture fill factor)

\begin{tabular}{llll}
\hline $\begin{array}{l}\text { Output pulse } \\
\text { length }(\mathrm{ns})\end{array}$ & $\begin{array}{l}\text { Fluence } \\
\left(\mathrm{J} / \mathrm{cm}^{2}\right)\end{array}$ & $\begin{array}{l}\text { Total Energy } \\
(\mathrm{kJ})\end{array}$ & $\begin{array}{l}\text { Spatial Intensity } \\
\text { modulation } \\
\text { (pk-avg.) }\end{array}$ \\
\hline 3 & 12.5 & 12.1 & $1.45: 1$ \\
5 & 14.3 & 13.9 & $1.25: 1$ \\
8 & 16 & 15.5 & $1.25: 1$ \\
\hline
\end{tabular}

Table 2. Summary of measured Beamlet $3 \omega$ performance characteristics.

$29.6 \times 29.6 \mathrm{~cm}^{2}$ beam, (effective area $736 \mathrm{~cm}^{2}, 84 \%$ aperture fill factor)

\begin{tabular}{ll}
\hline Parameter & Measured Performance \\
\hline Pulse width (ns) & 3 \\
Mean $3 \omega$ fluence $\left(\mathrm{J} / \mathrm{cm}^{2}\right)$ & 8.7 \\
$3 \omega$ energy $(\mathrm{kJ})$ & 6.4 \\
Bandwidth $(\mathrm{GHz})$ & 90 \\
Peak conversion efficiency $(\%)$ & 80 \\
Beam divergence $(\mu \mathrm{rad})$ & $\leq 25$ \\
Far field spot size & $\leq 2 \times$ diffraction limited \\
Strehl ratio & 0.4 \\
\hline
\end{tabular}

Auspices

This work was performed under the auspices of the U.S. Department of Energy by Lawrence Livermore National Laboratory under contract No. W-7405-Eng-48. 
Page 4 of 4

' Figure 1. Plan view of Beamlet laser

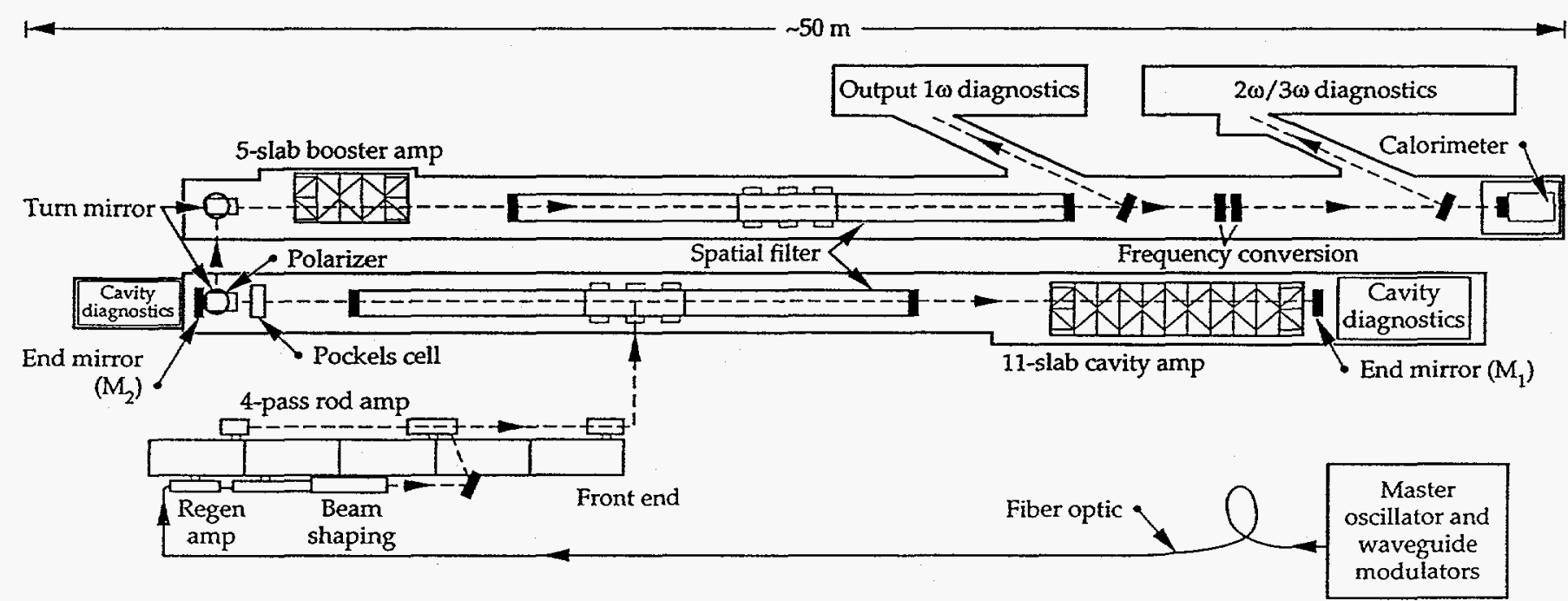

